\begin{tabular}{|c|c|}
\hline 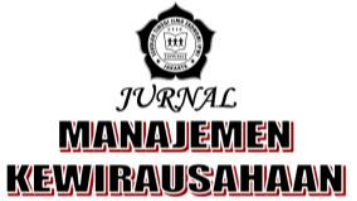 & $\begin{array}{r}\text { p-ISSN 1858-1048 } \\
\text { e-ISSN 2654-9247 } \\
\text { http://ejurnal.stieipwija.ac.id/index.php/jmk } \\
\text { DOI: } \underline{\text { http://dx.doi.org/10.33370/jmk.v16i1.311 }} \\
\text { Jurnal Manajemen Kewirausahaan Vol. 16 No. 01 - Juni } 2019 \\
\text { Submit: } 13 \text { Mei 2019; Review: 17 Jun 2019; Publish: 30 Jun } 2019\end{array}$ \\
\hline
\end{tabular}

\title{
KOMPETENSI DAN KOMPENSASI PENGARUHNYA TERHADAP KINERJA KARYAWAN DI SAMSUNG EXPERIENCE STORE LOTTE SHOPPING AVENUE
}

\author{
Oleh: \\ Yuli Triastuti'1), Jayadi2), Rivat Sutarto ${ }^{3)}$ \\ yulitrias@gmail.com ${ }^{1)}$, djayadi.ipwija@gmail.com ${ }^{2)}$, rivatargoebie93@gmail.com ${ }^{3)}$ \\ Sekolah Tinggi Ilmu Ekonomi IPWI Jakarta1,2,3)
}

\begin{abstract}
ABSTRAK
Kinerja karyawan di Samsung Experience Store Lotte Shopping Avenue dipengaruhi oleh beberapa faktor diantaranya adalah kompetensi dan kompensasi. Untuk membuktikan pengaruh keduanya maka dilakukan penelitian ini dengan tujuan untuk mengetahui pengaruh kompetensi dan kompensasi terhadap kinerja karyawan di Samsung Experience Store Lotte Shopping Avenue.

Penelitian dilakukan di Samsung Experience Store Lotte Shopping Avenue. Sampel yang digunakan pada penelitian ini adalah 30 responden atau merupakan sampel jenuh karena jumlah populasi yang ada di Samsung Experience Store Lotte Shopping Avenue 30 karyawan. Penelitian dilakukan secara kuantitatif yaitu dengan mendeskripsikan data penelitian dan melakukan analisis inferensi. Analisis regresi linier ganda dan koefisien determinasi ganda digunakan sebagai alat analisis sedangkan pengujian hipotesis dilakukan dengan uji-t dan uji-F dengan bantuan program SPSS v.24.

Hasil penelitian menunjukan bahwa: (1) Kompetensi memiliki pengaruh positif terhadap kinerja karyawan; (2) Kompensasi memiliki pengaruh positif terhadap kinerja karyawan.

Untuk meningkatkan kinerja karyawan disarankan meningkatkan kompetensi karyawan terus menerus karena kompetensi memiliki nilai yang lebih besar dibandingkan dengan kompensasi dalam mempengaruhi kinerja.
\end{abstract}

Kata Kunci: kompetensi, kompensasi, kinerja

\section{PENDAHULUAN}

Pada era globalisasi seperti sekarang ini peran dari manajemen sumber daya manusia (MSDM) masih merupakan tumpuan utama bagi perusahaan dalam menjalankan bisnisnya. Samsung Experience Store Lotte Shopping Avenue suatu perusahaan yang bergerak dalam penjualan handphone dan asesoris, merasakan bahwa kinerja pada perusahaan tersebut belum maksimal dalam arti penjualan tidak memenuhi target. Diketahui bahwa penjualan yang tidak memenuhi target disebabkan oleh banyak faktor. Faktor pertama tentu saja semakin banyaknya pesaing yang bergerak dalam bisnis yang sama. Faktor berikutnya karena kurangnya kompetensi yang dimiliki karyawan juga kompensasi yang diterima karyawan masih belum memadai.

Seperti halnya penelitian yang dilakukan Muhammad Riyanda (2017) dengan judul Pengaruh Kompetensi dan 
Disiplin Kerja terhadap Kinerja Pegawai pada Dinas Perizinan Kota Yogyakarta yang hasilnya kompetensi mempunyai pengaruh positif dan signifikan terhadap kinerja pegawai pada Dinas Perizinan Kota Yogyakarta. Jadi kompetensi merupakan unsur penting dalam peningkatan kinerja.

Juga penelitian yang dilakukan oleh Arie Pratama, dkk (2012) dengan judul Pengaruh Kompensasi dan Motivasi terhadap Kinerja pada PT Indo Stationery Ritel Utama Cabang Samarinda. Dimana Kompensasi mempunyai pengaruh yang signifikan terhadap kinerja. Hal ini dapat disimpulkan bahwa kompensasi tetap merupakan unsur penting dalam meningkatkan kinerja karyawan.

Dengan kompetensi yang tinggi, karyawan akan bekerja lebih giat di dalam melaksanakan pekerjaannya Begitu juga dengan kompensasi yang memadai dapat mendorong semangat bekerja, tidak mudah menyerah, dan dapat menyelesaikan pekerjaannya dengan baik, sehingga tujuan dari perusahaan dapat tercapai.

Hal ini pula berlaku pada Perusahaan Samsung Experience Lotte Shopping Avenue untuk dapat memenuhi target maka perlu diberikan pelatihan kepada karyawan sehingga kompetensi yang dimiliki oleh karyawan semakin meningkat begitu pula perlu adanya peninjauan kembali sistem kompensasi yang berlaku.

Berdasarkan latar belakang tersebut maka peneliti melakukan suatu pengkajian yang lebih mendalam tentang kompetensi dan kompensasi serta pengaruhnya terhadap peningkatan kinerja karyawan.

\section{TUJUAN PENELITIAN}

1. Untuk mengetahui apakah kempetensi mempunyai pengaruh terhadap kinerja karyawan di Samsung Ecperience Lotte Shoping Avenue.

2. Untuk mengetahui apakah kompensasi mempunyai pengaruh terhadap kinerja di Samsung Experience Lotte Shoping Avenue.

\section{TELAAH LITERATUR DAN PENGEMBANGAN HIPOTESIS Kompetensi}

Kompetensi merupakan suatu kemampuan untuk melaksanakan atau melakukan suatu pekerjaan atau tugas yang dilandasi atas ketrampilan dan pengetahuan serta didukung oleh sikap kerja yang dituntut oleh pekerjaan tersebut, kompetensi menunjukkan ketrampilan atau pengetahuan yang dicirikan oleh profesionalisme dalam suatu bidang tertentu sebagai sesuatu yang terpenting, sebagai unggulan bidang tersebut (Wibowo, 2017:72).

Seorang karyawan yang mempunyai kompetensi yang tinggi dapat menjalankan pekerjaan dengan baik, karena pengaruh kompetensi signifikan terhadap kinerja hal ini sesuai dengan penelitian terdahulu yang dilakukan oleh Radian Danu Saputra (2016) dengan judul Pengaruh Kompetensi Karyawan dan Lingkungan Kerja terhadap Kinerja Karyawan PT. PLN (Persero) Distribusi Lampung.

Hal ini sesuai juga dengan penelitian yang dilakukan oleh Sholehatusya'diah (2016) dengan judul Pengaruh Kompetensi Kerja terhadap Kinerja Karyawan di Kantor PT. Kitadin Tenggarong Seberang dimana hasilnya variabel kompetensi kerja (pengetahuan, keterampilan dan kemampuan) mempunyai hubungan positif yang signifikan terhadap kinerja karyawan (kualitas, kuantitas, penggunaan waktu, kerjasama dan kedisplinan) pada Kantor PT. Kitadin Tenggarong Seberang.

Setiap organisasi, private, atau public perlu membangun sumber daya manusia (SDM) yang dimiliki secera profesional dan memiliki kompetensi yang tinggi. SDM yang berkompetensi tinggi akan menjadi posat keunggulan organisasi.

\section{Faktor-faktor yang Mempengaruhi Kompetensi}

Zwell (2000:56-68), beberapa faktor yang mempengaruhi kecakapan kompetensi seseorang yaitu:

1. Keyakinan dan nilai-nilai

2. Keterampilan

3. Pengalaman 
4. Karakteristik kepribadian

5. Motivasi

6. Isu emosional

7. Kemampuan intelektual

8. Budaya organisasi

Dengan demikian dapat disimpulkan bahwa kompetensi merupakan kemampuan atau ketrampilan yang berhubungan dengan kegitatan berpikir sebagai agen perubahan sosial, penggerak untuk melaksanakan tugas dan berguna untuk menciptakan budaya kinerja yang tinggi.

\section{Kompensasi}

Kompensasi merupakan balas jasa secara periodik yang diberikan kepada karyawan dari perusahaan. Pengertian kompensasi menurut Drs. Malayu S.P. Hasibuan (2005) adalah semua pendapatan yang berbentuk uang, barang langsung atau tidak langsung yang diterima karyawan sebagai imbalan atas jasa yang diberikan kepada perusahaan. Menurut Tulus dalam Jurnal Bahrul Yaman (2009) kompensasi atau balas jasa didefinisikan sebagai pemberian penghargaan langsung maupun tidak langsung, financial maupun non-finansial yang adil dan layak kepada karyawan atas sumbangan mereka dalam pencapaian tujuan organisasi.

Kompensasi merupakan sebuah komponen penting dalam hubungannya dengan karyawan. Kompensasi sangat dipengaruhi faktor-faktor internal dan eksternal perusahaan. Kompensasi sangat dipengaruhi oleh tekanantekanan faktor-faktor pasar kerja, peraturan pemerintah, filosofi manajemen puncak tentang pembayaran dan manfaat termasuk tentang kompensasi internasional (Mangkuprawira, 2004).

Adapun menurut Nunung Ristiana (2012) dalam penelitiannya dengan judul Pengaruh Kompensasi, Lingkungan Kerja dan Motivasi terhadap Kinerja Guru Tidak Tetap (studi pada SD/MI Kabupaten Kudus) diperoleh hasil penelitiannya adalah kompensasi berpengaruh positif dan signifikan terhadap kinerja guru tidak tetap.
Seperti halnya penelitian yang dilakukan oleh Gusti (2013) dengan judul Analisis Pengaruh Kepemimpinan, Kompensasi dan Kompetensi terhadap Kinerja Pegawai pada Dinas Koperasi, UMKM dan Perdagangan Provinsi DKI Jakarta dengan hasil kompensasi berpengaruh positif dan signifikan terhadap kinerja pegawai pada Dinas Koperasi, UMKM dan Perdagangan Provinsi DKI Jakarta.

Menurut penelitian yang dilakukan oleh Evi Apriani Ulfah (2015) dengan judul Pengaruh Motivasi dan Kompensasi terhadap Kinerja Guru di MTS Al-Ittihad Kecamatan Tanjungsari Kabupaten Bogor dengan hasil ada pengaruh yang signifikan variabel kompensasi terhadap kinerja guru. Dibuktikan dengan hasil nilai sig $0.033<0.05$ artinya Ho ditolak dan Ha diterima.

\section{Jenis-jenis Kompensasi}

Kompensasi merupakan cara perusahaan untuk meningkatkan kualitas karyawannya untuk pertumbuhan perusahaan. Setiap perusahaan memiliki suatu sistem kompensasi yang berbeda-beda sesuai dengan visi, misi, dan tujuannya. Menurut Gugup Kismono (2011) kompensasi dapat dibedakan dalam dua kategori, yaitu:

1) Kompensasi Finansial (Uang)

Kompensasi langsung berupa pembayaran upah (pembayaran atas dasar jam kerja), gaji (pembayaran secara tetap/bulanan), dan insentif atau bonus. Pemberian gaji tetap setiap bulannya umumnya didasarkan pada nilai pekerjaan yang diembannya. Semakin tinggi nilai pekerjaan atau jabatannya akan semakin tinggi pula gaji yang diterimanya tanpa mempertimbangkan kinerja yang dihasilkannya. Penentuan nilai sebuah pekerjaan dilakukan melalui evaluasi pekerjaan. Sebaliknya, besar-kecilnya gaji insentif atau bonus dikaitkan dengan kinerja seseorang atau kinerja organisasi. Jika seseorang menunjukkan kinerja yang lebih tinggi dibandingkan rekan kerjanya, maka dia berhak 
mendapatkan insentif lebih besar walaupun mereka menduduki jabatan yang sama. Kompensasi pelengkap atau tidak langsung (benefits), pemberian pelayanan dan fasilitas kepada karyawan seperti program beasiswa pendidikan, perumahan, program rekreasi, libur dan cuti, konseling financial, dan lain-lain.

2) Kompensasi Nonfinansial (Nonuang)

- Kepuasan dari pekerjaan itu sendiri, yaitu tugas-tugas yang menarik, tantangan, tanggung jawab, pengakuan, dan rasa pencapaian.

- Kepuasan yang diperoleh dari lingkungan kerja karyawan, yaitu kebijakan yang sehat, supervisi yang kompeten, kerabat kerja yang menyenangkan, dan lingkungan kerja yang nyaman.

\section{Faktor-faktor yang Mempengaruhi Kompensasi}

Menurut Drs. Malayu S. P. Hasibuan (2005) faktor-faktor yang mempengaruhi besarnya kompensasi, antara lain yaitu:

a. Penawaran dan permintaan tenaga kerja;

b. Kemampuan yang dan kesediaan perusahaan;

c. Serikat buruh/organisai karyawan;

d. Produktivitas kerja karyawan;

e. Pemerintah dengan undang-undang dan keppresnya;

f. Biaya hidup/cost of living;

g. Posisi jabatan karyawan;

h. Pendidikan dan pengalaman karyawan;

i. Kondisi perekonomian nasional;

j. Jenis dan sifat pekerjaan;

Dari uraian di atas dapat diketahui bahwa penawaran dan permintaan akan tenaga kerja mempengaruhi program kompensasi, dimana jika penawaran jumlah tenaga kerja langka gaji cenderung tinggi, sebaliknya jika permintaan tenaga kerja yang berkurang/kesempatan kerja menjadi langka, gaji cenderung rendah.

\section{Proses dalam Kebijakan Kompensasi} Menurut Gugup Kismono (2011) dalam melaksanakan kebijakan kompensasi, perlu dikaji adanya peraturan tentang kompensasi dengan maksud agar dapat memberikan balas jasa kepada karyawan secara adil dan terstruktur sehingga akan memperlancar administrasi penggajian dan untuk memotivasi karyawan supaya berprestasi. Berbagai peralatan, sistem dan kebijaksanaan dapat digunakan untuk mempermudah proses administrasi yang kompleks. Metode yang dapat digunakan adalah dengan:

- Analisis pekerjaan;

- Evaluasi pekerjaan;

- Survei pengupahan dan penggajian;

- Rencana-rencana kompensasi variabel;

- Penilaian kinerja dan lain-lain.

\section{Kinerja Karyawan}

Menurut Kamus Besar Bahasa Indonesia (2005:570) memberikan definisi kinerja diartikan sebagai: (1) sesuatu yang dicapai, (2) prestasi yang diperlihatkan, (3) kemampuan kerja. Snell SA (1992:329) menyatakan bahwa kinerja merupakan kulminasi dari tiga elemen yang saling berkaitan, yakni keterampilan, upaya, bersifat eksternal. Tingkat keterampilan merupakan bahan baku yang dibawa oleh seseorang ke tempat kerjanya, seperti pengetahuan, kemampuan, kecakapan interpersonal serta kecakapan-kecakapan teknis. Tingkat upaya dapat digambarkan sebagai motivasi yang diperlihatkan oleh seseorang untuk menyelesaikan pekerjaan. Sedangkan kondisi-kondisi eksternal adalah tingkat sejauh mana kondisi-kondisi eksternal mendukung kinerja seseorang. Kinerja adalah suatu ukuran yang mencakup keefektifan dalam pencapaian tujuan dan efesiensi yang merupakan rasio dari keluaran efektif terhadap masukan yang diperlukan untuk mencapai tujuan itu (Robbins, 1996:24).

Handoko (1998:7), dua konsepsi utama untuk mengukur kinerja (performance) seseorang adalah efisiensi dan efektifitas. Efisiensi adalah kemampuan untuk menyelesaikan suatu pekerjaan dengan benar. Efisiensi ini merupakan konsep matematik atau merupakan perhitungan rasio antara 
pengeluaran (output) dan masukan (input). Seorang pegawai yang efisien adalah seorang yang mencapai keluaran yang lebih tinggi (hasil, produktifitas, kinerja) dibanding masukan-masukan (tenaga kerja, bahan, uang, mesin dan waktu). Dengan kata lain, dapat memaksimumkan keluaran dengan jumlah masukan yang terbatas. Sedangkan efektifitas merupakan kemampuan untuk memilih tujuan yang tepat atau peralatan yang tepat untuk pencapaian tujuan yang telah ditetapkan. Dengan kata lain, seorang pegawai yang efektif adalah seorang yang dapat memilih pekerjaan yang harus dilakukan dengan metode (cara) yang tepat untuk mencapai tujuan.

\section{Faktor-Faktor yang Mempengaruhi Kinerja}

Para pimpinan perusahaan atau kantor sangat menyadari bahwa ada perbedaan kinerja antara seorang pegawai dengan pegawai lainnya yang berada di bawah pengawasannya. Walaupun para pegawai bekerja pada bagian yang sama, namun produktivitas mereka bisa tidak sama. Keith Davis (1985:484) faktor yang mempengaruhi pencapaian kinerja adalah faktor kemampuan (ability) dan faktor motivasi (motivation). Sedangkan Robbins (1996:224), bahwa kinerja karyawan itu dipengaruhi oleh tiga faktor, yaitu kemampuan (ability), motivasi (motivation), dan kesempatan (opportunity). Penilaian kerja pegawai didasarkan atas penilaian dan kemampuan dari karyawan yang bersangkutan dengan menilai faktorfaktor kemampuan, disiplin, dan kreativitas. Kinerja merupakan cerminan dari motivasi karyawan yang dinilai. Jadi tinggi rendahnya kinerja pegawai tergantung dari cerminan perilaku dan kemampuan (motivasi) pegawai dalam melaksanakan tugas yang dibebankan kepadanya.

\section{Indikator Kinerja}

Standar pekerjaan dapat ditentukan dari isi suatu pekerjaan, dapat dijadikan sebagai dasar penilaian setiap pekerjaan.untuk memudahkan penilaian kinerja karyawan, standar pekerjaan harus dapat diukur dan dipahami secara jelas. Suatu pekerjaan dapat diukur melalui kualitas, kuantitas, dan ketepatan waktu mengerjakannya.

Adapun indikator dari kinerja karyawan menurut Wibowo (2012:233234) adalah sebagai berikut:

a) Kualitas

Setiap karyawan dalam instansi harus memenuhi persyaratan tertentu untuk dapat menghasilkan pekerjaan sesuai kualitas yang dituntut suatu pekerjaan tertentu. Setiap pekerjaan mempunyai standar kualitas tertentu yang harus disesuaikan oleh karyawan untuk dapat mengerjakan sesuatu tertentu. Karyawan memiliki kinerja baik bila dapat menghasilkan pekerjaan sesuai persyaratan kualitas yang dituntut pekerjaan tersebut.

b) Kuantitas

Dimensi ini menunjukan jumlah pekerjaan yang dihasilkan individu atau kelompok sebagai persyaratan yang menjadi standar pekerjaan. Setiap pekerjaan memiliki persyaratan yang beda sehingga menuntut karyawan harus memenuhi persyaratan tersebut baik pengetahuan, keterampilan, maupun kemampuan sesuai. Berdasarkan persyaratan pekerjaan tersebut dapat diketahui jumlah karyawan yang dibutuhkan untuk dapat mengerjakannya, atau setiap karyawan dapat mengerjakan berapa unit pekerjaan.

c) Ketetapan Waktu

Setiap pekerjaan memiliki karateristik yang berbeda, untuk jenis pekeraan tertentu harus diselesaikan tepat waktu, karena memiliki ketergantungan atas pekerjaan lainnya. Jadi, bila pekerjaan pada suatu bagian tertentu tidak selesai tepat waktu akan menghambat pekerjaan pada bagian lain, sehingga mempengaruhi jumlah dan kualitas hasil pekerjaan.

\section{Kerangka Pemikiran}

Berdasarkan teori tentang kompetensi dan kompensasi yang telah 
dikemukakan di atas, maka dengan ini peneliti menetapkan bahwa peningkatan kinerja karyawan di Samsung Experience Store Lotte Shopping Avenue sangat dipengaruhi oleh kompetensi dan kompensasi yang telah diterapkan oleh pimpinan organisasi / perusahaan. Oleh karena itu, berdasarkan uraian di atas untuk meningkatkan kinerja dari karyawan perlu menganalisa terlebih dahulu tentang kompetensi dan kompensasi berdasarkan kajian teori yang ada sehingga dapat diketahui pengaruhnya terhadap kinerja karyawan. Pengaruh antar variabel dalam penelitian ini dapat digambarkan sebagai berikut:

Gambar 1

Kerangka/Konstelasi

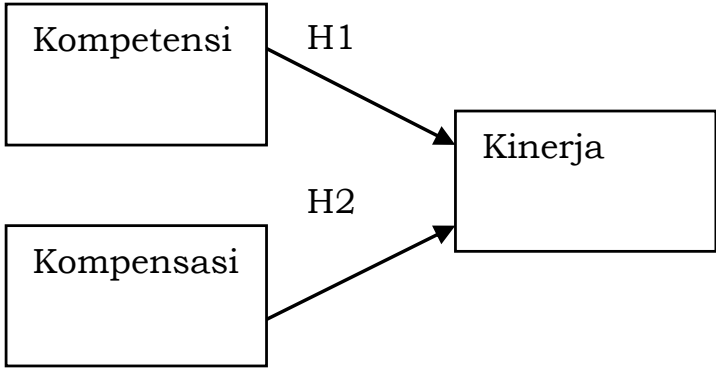

H1: Terdapat pengaruh kompetensi terhadap kinerja karyawan Samsung Experience Store Lotte Shopping Avenue.

H2: Terdapat pengaruh kompensasi terhadap kinerja karyawan Samsung Experience Store Lotte Shopping Avenue.

\section{METODE PENELITIAN}

Penelitian ini diadakan di Samsung Experience Store Lotte Shopping Avenue.

\section{Sampel Penelitian}

Populasi pada penelitian ini adalah seluruh karyawan dengan jumlah 30 orang. Untuk itu, sampel yang digunakan adalah sampel jenuh atau seluruh populasi digunakan sebagai sampel.

\section{Desain Penelitian}

Jenis penelitian yang digunakan dalam penelitian ini adalah explanatory research tipe kausal menguji pengaruh variabel independen terhadap terhadap variabel dependen. Lingkup penelitian ini adalah menguji pengaruh kompetensi dan kompensasi terhadap kinerja.
Dalam penelitian ini terdapat tiga variabel, yaitu variabel bebas ada dua dan satu variabel terikat. Variabel bebas yang pertama yaitu kompetensi dengan simbol X1 dan variabel bebas yang kedua yaitu kompensasi dengan simbol X2. Satu variabel terikat yaitu kinerja dengan simbol Y.

\section{Operasionalisasi Variabel}

Operasionalisasi variabel berupa definisi dan indikator masing-masing variable sebagai berikut:

Tabel 1

Operasionalisasi Variabel

\begin{tabular}{|c|c|c|}
\hline Variabel & Dimensi & Indikator \\
\hline $\begin{array}{l}\text { Kompetensi } \\
\text { Kompetensi } \\
\text { (X1) } \\
\text { merupakan } \\
\text { suatu } \\
\text { kemampuan } \\
\text { untuk } \\
\text { melaksanakan } \\
\text { atau } \\
\text { melakukan } \\
\text { suatu } \\
\text { pekerjaan atau } \\
\text { tugas yang } \\
\text { dilandasi atas } \\
\text { ketrampilan } \\
\text { dan } \\
\text { pengetahuan } \\
\text { (Wibowo, 2017: } \\
\text { 27) }\end{array}$ & $\begin{array}{l}\text { 3. Kemampuan } \\
\text { individu } \\
\text { (Personality) }\end{array}$ & $\begin{array}{l}\text { - } \text { Mengerti ilmu } \\
\text { manajemen } \\
\text { - Memahami } \\
\text { tupoksi yang } \\
\text { berlaku } \\
\text { - Keasadaran } \\
\text { berorganisasi } \\
\text { - Kemampuan } \\
\text { memimpin } \\
\text { - Kemampuan } \\
\text { mempengaruh } \\
\text { i orang lain } \\
\text { - Fleksibilitas } \\
\text { - Pemahaman } \\
\text { antar pribadi } \\
\text { - Menjalin } \\
\text { hubungan } \\
\text { - Tingkat } \\
\text { kemampuan } \\
\text { pengembanga } \\
\text { n diri } \\
\text { - Kemampuan } \\
\text { pribadi }\end{array}$ \\
\hline \begin{tabular}{|l} 
Kompensasi \\
Kompensasi \\
(X2) adalah \\
semua \\
pendapatan \\
yang berbentuk \\
uang, barang \\
langsung atau \\
tidak langsung \\
yang diterima \\
karyawan \\
sebagai \\
imbalan atas \\
jasa yang \\
diberikan \\
kepada \\
perusahaan. \\
(Malayu \\
Hasibuan, \\
2014:27)
\end{tabular} & \begin{tabular}{|ll} 
1. & $\begin{array}{l}\text { Proses } \\
\text { kebijakan } \\
\text { kompensasi }\end{array}$ \\
2. & $\begin{array}{l}\text { Penerimaan } \\
\text { kompensasi } \\
\text { yang sesuai }\end{array}$
\end{tabular} & - Insentif \\
\hline
\end{tabular}




\begin{tabular}{|c|c|c|}
\hline Variabel & Dimensi & Indikator \\
\hline $\begin{array}{l}\text { Kinerja } \\
\text { Kinerja } \\
\text { Karyawan (Y) } \\
\text { adalah fungsi } \\
\text { dari motivasi, } \\
\text { kecakapan dan } \\
\text { persepsi } \\
\text { peranan oleh } \\
\text { karyawan } \\
\text { tersebut dalam } \\
\text { pekerjaannya } \\
\text { (Stoner) } \\
\text { (Wibowo, } \\
\text { 2016:59) }\end{array}$ & 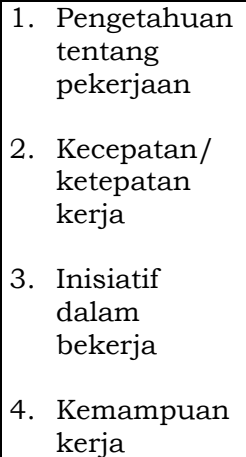 & $\begin{array}{l}\text { - Kualitas kerja } \\
\text { - Kuantitas } \\
\text { kerja } \\
\text { - Hasil kerja } \\
\text { - Tepat waktu } \\
\text { - Sesuai target }\end{array}$ \\
\hline
\end{tabular}

\section{Metode Analisis}

Analisis yang digunakan dalam penelitian ini adalah model persamaan linier sebagai berikut: $\mathrm{Y}=\mathrm{a}+\mathrm{bX} 1+\mathrm{bX} 2$ Dimana:

$\mathrm{Y}=$ Subjek variabel terikat yang diproyeksikan

$\mathrm{a}=$ Nilai konstanta

$\mathrm{b}=$ Nilai arah sebagai penentu ramalan variabel $\mathrm{Y}$

$\mathrm{x}=$ Variabel bebas yang mempunyai nilai tertentu untuk diprediksikan

(Riduwan, 2007:96).

\section{Rancangan Pengujian Hipotesis}

1. Hipotesis pertama yang diajukan dalam penelitian ini adalah terdapat pengaruh yang signifikan variabel kompetensi terhadap kinerja karyawan Samsung Experience Store Lotte Shopping Avenue. Pengaruhnya ditunjukkan oleh nilai koefisien regresi kompetensi (X1) sebesar b1 pada model persamaan regresi linier ganda $\mathrm{Y}=\mathrm{a}+\mathrm{bX} 1+$ bX2. Hipotesis statistik yang diajukan adalah sebagai berikut:

$\mathrm{H} 1 \mathrm{o}: \mathrm{b} 1=0$ : tidak ada pengaruh $\mathrm{H} 1 \mathrm{a}: \mathrm{b} 1 \neq 0$ : ada pengaruh Jika $b 1 \neq 0$ dan probabilitas thitung lebih kecil daripada taraf uji penelitian ( $\mathrm{sig} \mathrm{t}<\mathrm{a}$ atau $0,000<$ 0,05), maka H1o ditolak dan $\mathrm{H} 1 \mathrm{a}$ diterima yang berarti pengaruh kompetensi (X1) terhadap kinerja (Y) adalah signifikan.

2. Hipotesis kedua yang diajukan dalam penelitian ini adalah terdapat pengaruh yang signifikan variabel kompensai terhadap kinerja karyawan Samsung Experience Store Lotte Shopping Avenue. Pengaruhnya ditunjukkan oleh nilai koefisien regresi kompensasi (X1) sebesar b2 pada model persamaan regresi linier ganda $\mathrm{Y}=\mathrm{a}+\mathrm{bX} 1+$ bX2. Hipotesis statistik yang diajukan adalah sebagai berikut:

$\mathrm{H} 2 \mathrm{o}: \mathrm{b} 2=0$ : tidak ada pengaruh $\mathrm{H} 2 \mathrm{a}: \mathrm{b} 2 \neq 0$ : ada pengaruh

Jika $\mathrm{b} 2 \neq 0$ dan probabilitas $\mathrm{t}$ hitung lebih kecil daripada taraf uji penelitian ( $\operatorname{sig} \mathrm{t}<\mathrm{a}$ atau $0,000<$ 0,05), maka $\mathrm{H} 2 \mathrm{o}$ ditolak dan $\mathrm{H} 2 \mathrm{a}$ diterima yang berarti pengaruh kompensasi (X2) terhadap kinerja (Y) adalah signifikan.

\section{HASIL DAN PEMBAHASAN Hasil Penelitian}

Dalam penelitian ini terdapat dua variabel bebas yaitu kompetensi dan kompensasi yang mempengaruhi variabel terikat yaitu kinerja karyawan. Penelitian ini bertujuan untuk mengetahui pengaruh kompetensi dan kompensasi terhadap kinerja karyawan di Samsung Experience Store Lotte Shopping Avenue. Pengukuran variabel penelitian dilakukan dengan menggunakan kuesioner yang dikembangkan dari indikator pada masing masing variabel penelitian.

Dari uji validitas terhadap masingmasing variabel penelitian ditemukan bahwa semua item pertanyaan dalam kuesioner penelitian mempunyai koefisien korelasi $r$ hitung yang lebih besar dari $r$ tabel $=0,1966$ sehingga item pertanyaan tersebut valid. Melalui uji reliabilitas ditemukan bahwa keseluruhan variabel memiliki Cronbach Alpha yang lebih besar dari 0,60, sehingga variabel penelitian ini dapat dibuktikan reliabilitasnya. Karena kuesioner telah valid dan reliabel maka kuesioner penelitian merupakan alat yang handal untuk mengukur masingmasing variabel penelitian.

Analisis deskriptif terhadap variabel penelitian menghasilkan temuan yang relatif sama untuk semua variabel penelitian dimana persepsi responden 
terhadap kompetensi dan kompensasi, serta kinerja karyawan cenderung baik.

Penelitian menghasilkan model persamaan regresi linier ganda $\mathrm{Y}=0.533$ $+0.556 \mathrm{X} 1+0.330 \mathrm{X} 2$ yang menunjukan pengaruh kompetensi dan kompensasi terhadap kinerja.

\section{Pengujian Hipotesis \\ Pengujian Hipotesis 1:}

Pengaruh kompetensi terhadap kinerja ditunjukkan oleh nilai koefisien regresi kompetensi 0.556 (X1) sebesar b1 $=0,556$ pada model persamaan regresi linier ganda $\mathrm{Y}=0.533+0.556 \mathrm{X} 1+$ $0.330 \times 2$. Koefisien regresi kompetensi (X1) sebesar $\mathrm{b} 1=0,556$ memiliki nilai probabilitas $t$ hitung sebesar 0,000. Karena $b 1 \neq 0$ dan probabilitas t hitung lebih kecil daripada taraf uji penelitian ( sig $\mathrm{t}<\mathrm{a}$ atau $0,000<0,05)$, maka H1o ditolak dan $\mathrm{H} 1 \mathrm{a}$ diterima yang berarti pengaruh kompetensi (X1) terhadap kinerja $(\mathrm{Y})$ adalah signifikan. Signifikansi hasil pengujian menunjukkan bahwa hipotesis pertama penelitian ini diterima yang berarti kompetensi mempunyai pengaruh yang positif dan signifikan terhadap kinerja.

\section{Pengujian Hipotesis 2}

Pengaruh kompensasi terhadap kinerja ditunjukkan oleh nilai koefisien regresi kompensasi (X2) sebesar b2 = 0,330 pada model persamaan regresi linier ganda $\mathrm{Y}=0.533+0.556 \mathrm{X} 1+$ $0.330 X 2$. Koefisien regresi kompensasi (X2) sebesar b2 $=0,330$ memiliki nilai probabilitas $t$ hitung sebesar 0,000 . Karena $\mathrm{b} 1 \neq 0$ dan probabilitas $\mathrm{t}$ hitung lebih kecil daripada taraf uji penelitian ( sig $\mathrm{t}<\mathrm{a}$ atau 0,000 $<0,05$ ), maka H2o ditolak dan $\mathrm{H} 2 \mathrm{a}$ diterima yang berarti pengaruh kompensasi (X2) terhadap kinerja karyawan (Y) adalah signifikan. Signifikansi hasil pengujian menunjukkan bahwa hipotesis kedua penelitian ini diterima yang berarti kompensasi mempunyai arah yang positif dan signifikan terhadap kinerja.

\section{Pembahasan}

\section{Pengaruh Kompetensi terhadap} Kinerja Karywan

Kompetensi memiliki pengaruh signifikan sebesar $56,6 \%$ terhadap kinerja karyawan dengan arah positif, artinya makin tinggi kompetensi maka makin tinggi pula kinerja karyawan. Pengaruh kompetensi terhadap kinerja karyawan ditunjukkan oleh nilai koefisien regresi kompetensi sebesar $\mathrm{b} 1=$ 0,556 pada model persamaan regresi linier ganda $\mathrm{Y}=0.533+0.556 \mathrm{X} 1+$ 0.330X2.

Faktor pertama yang mempengaruhi kinerja karyawan adalah kompetensi. Kompetensi merupakan suatu kemampuan untuk melaksanakan atau melakukan suatu pekerjaan atau tugas yang dilandasi atas ketrampilan dan pengetahuan.

Hal ini sesuai dengan penelitian yang dilakukan oleh Muhammad Riyanda (2017) dengan judul Pengaruh Kompetensi dan Disiplin Kerja terhadap Kinerja Pegawai pada Dinas Perizinan Kota Yogyakarta yang hasilnya kompetensi mempunyai pengaruh positif dan signifikan terhadap kinerja pegawai pada Dinas Perizinan Kota Yogyakarta. Jadi kompetensi merupakan unsur penting dalam peningkatan kinerja.

\section{Pengaruh Kompensasi terhadap Kinerja Karyawan}

Kompensasi memiliki pengaruh signifikan sebesar 33,0 \% terhadap kinerja karyawan dengan arah positif, artinya makin tinggi kompensasi maka makin tinggi pula kinerja karyawan. Pengaruh kompensasi terhadap kinerja karyawan ditunjukkan oleh nilai koefisien regresi kompensasi sebesar b2 $=0,330$ pada model persamaan regresi linier ganda $\mathrm{Y}=0.533+0.556 \mathrm{X} 1+$ $0.330 \times 2$. 
Hasil penelitian ini sesuai dengan penelitian yang dilakukan oleh Gusti (2013) dengan judul Analisis Pengaruh Kepemimpinan, Kompensasi dan Kompetensi terhadap Kinerja Pegawai pada Dinas Koperasi, UMKM dan Perdagangan Provinsi DKI Jakarta dengan hasil kompensasi berpengaruh positif dan signifikan terhadap kinerja pegawai pada Dinas Koperasi, UMKM dan Perdagangan Provinsi DKI Jakarta.

\section{KESIMPULAN \\ Simpulan}

Penelitian menghasilkan persamaan regresi linier ganda sebagai berikut:

$\mathrm{Y}=0.533+0.556 \mathrm{X} 1+0.330 \mathrm{X} 2$

1. Kompetensi mempunyai pengaruh terhadap kinerja karyawan di Samsung Ecperience Lotte Shoping Avenue dengan arah positif; artinya makin tinggi kompetensi karyawan maka kinerja karyawan akan semakin baik.

2. Kompensasi mempunyai pengaruh terhadap kinerja di Samsung Experience Lotte Shoping Avenue dengan arah positif; artinya makin tinggi kompensasi yang diterima karyawan maka kinerja karyawan akan semakin baik.

\section{Saran}

1. Perusahaan harus melakukan penilaian prestasi sehingga dapat terdeteksi kompetensi dari karyawan.

2. Selalu melakukan evaluasi terhadap kelangsungan perusahaan secara periodik.

\section{DAFTAR PUSTAKA}

Danu, Radian. (2016). Pengaruh Kompetensi Karyawan dan Lingkungan Kerja terhadap Kinerja Karyawan pada PT. PLN (Persero) Distribusi Lampung, Skripsi, Unila, Bandar Lampung.

Gusti. (2013). Analisis Pengaruh Kepemimpinan, Kompensasi dan Kompetensi terhadap Kinerja Pegawai pada Dinas Koperasi, UMKM dan Perdagangan Provinsi DKI Jakarta.
Hasibuan, Malayu S. P. (2005), Manajemen Sumber Daya Manusia (Revisi Ed). Jakarta: Bumi Aksara. (2014). Manajemen Sumber Daya Manusia. Jakarta: Bumi Aksara.

Kismono, Gugup. (2011). Bisnis Pengantar (2 ed). BPFE UGM: Yogyakarta.

Mangkunegara, A.A, Anwar Prabu. (2008). Manajemen Sumber Daya Manusia Perusahaan. Bandung: PT. Rafika Aditama. . (2014). Evaluasi Kinerja SDM. Bandung: PT Refika Aditama.

Mulyanto, H dan Wulandari, A. (2010). Penelitian: Metode dan Analisis. Semarang: CV. Agung.

Pratama, Arie, dkk. (2012). Pengaruh Kompensasi dan Motivasi terhadap Kinerja pada PT Indo Stationery Ritel Utama Cabang Samarinda. Publikasi Imiah. Universitas Mulawarman.

Ristiana Nunung. (2012). Pengaruh Kompetensi, Lingkungan Kerja, dan Motivasi terhadap Kinerja Guru Tidak Tetap pada SD/MI Kabupaten Kudus. Skripsi. Universitas Muria, Kudus.

Rivai, Veithzal. (2006). Manajemen Sumber Daya Manusia untuk Perusahaan, dari Teori ke Praktek (1 ed). Jakarta: PT. RajaGrafindo Persada.

Riyanda, Muhammad. (2017). Pengaruh Kompetensi dan Disiplin Kerja terhadap Kinerja Pegawai pada Dinas Perizinan Kota Yogyakarta. Skripsi, Universitas Negeri Yogyakarta.

Sholehatusya'diah. (2016). Pengaruh Kompetensi Kerja terhadap Kinerja Karyawan di Kantor PT. Kitadin Tenggarong Seberang, Ejurnal Ilmu Administrasi Negara Vol. 5 No. 2, 5789, Universitas Mulawarman.

Sutrisno, Edy. (2016). Manajemen Sumber Daya Manusia. Jakarta: Penerbit Kencana.

Ulfah, Evi Apriani. (2015). Pengaruh Motivasi dan Kompensasi terhadap Kinerja Guru di MTS Al-Ittihad Kecamatan Tanjungsari Kabupaten Bogor. Skripsi. Bogor. 
Wibowo. (2013). Manajemen Kinerja (4 ed). Depok: Penerbit Raja Grafindo Persada.
Zwell, Michael. (2000). Creating a Culture

of Competence. New York: John Wiley \& Sons, Inc. 